Marek SKRZYNIARZ, Artur ROJEK, Włodzimierz KRUCZEK, Kamil MIKE, Łukasz MROCZKOWSKI, Piotr STYPUŁKOWSKI

Railway Institute (Instytut Kolejnictwa)

\title{
ANALYSIS OF THE OPERATING MODES OF THE STATIONARY ENERGY STORAGE DEVICE IN DC RAILWAY POWER SUPPLY SYSTEM
}

\author{
Analiza trybów pracy stacjonarnego magazynu energii \\ w kolejowym systemie zasilania prądu stalego
}

\begin{abstract}
This article analyzes the operating modes of the energy storage. The aim was to conduct laboratory tests in conditions similar to real energy storage and to analyze its basic electrical parameters. A special measuring system has been created for laboratory testing. Real tests took place in the traction substation in Mińsk Mazowiecki, where the energy storage was included in the traction substation system. Based on the laboratory tests carried out and in real conditions it was found that the use of energy storage in the electric traction supply system is justified. It is adapted to work as a device supporting the operation of the traction substation and the section cabin.
\end{abstract}

Keywords: energy storage, supercapacitors, traction substation, section cabin

Streszczenie: W niniejszym artykule przeanalizowano tryby pracy magazynu energii. Celem byto przeprowadzenie badan laboratoryjnych, w warunkach zblizonych do rzeczywistych magazynu energii oraz analiza jego podstawowych parametrów elektrycznych. Do badań laboratoryjnych zostat stworzony specjalny uktad pomiarowy. Badania rzeczywiste odbyty się w podstacji trakcyjnej w Mińsku Mazowieckim, gdzie magazyn energii został właczony do uktadu podstacji trakcyjnej. Na podstawie przeprowadzonych badan laboratoryjnych $i w$ warunkach rzeczywistych stwierdzono, iż stosowanie magazynu energii $w$ systemie zasilania trakcji elektrycznej jest zasadne. Jest on przystosowany do pracy jako urzadzenie wspierajace prace podstacji trakcyjnej i kabiny sekcyjnej.

Słowa kluczowe: magazyn energii, superkondensatory, podstacja trakcyjna, kabina sekcyjna 


\section{Introduction}

As part of the European Green Deal, the Commission proposed in September 2020 to raise the 2030 greenhouse gas emission reduction target, including emissions and removals, to at least $55 \%$ compared to 1990 [20].

Moreover, energy saving on railway traction is an important part of these activities. Among other technical solutions reducing $\mathrm{CO} 2$ emission in power supply system there is a possibility to use energy storage devices. The issue of reducing $\mathrm{CO} 2$ emissions is in line not only with the strategy of the European Union [20] but also with the PKP "Green Railway" program [19].

The idea of supporting the electric power supply system by energy storage is not new one. It occurs, among others, in the power supply of trolleybuses [2,17], tram traction $[4,14,15]$, hybrid cars $[16,18]$. With the development of supercapacitor technology, it also began to function in railway traction [5-8].

One can distinguish energy storage located on the traction vehicle or stationary devices in traction substations or section cabins. The authors of article [10] investigated advantages and disadvantages the use of on-board energy storage device in light rail transportation systems. In the article it was examined the use of on-board energy storage device with batteries for a catenary free section for different scenarios (full route or a catenary free section between two stations); the charge of on-board energy storage device between stations (in parallel with tram motoring) to decrease the charging dwell time at stations and to help in achieving the operational timetable; the thermal effect of the additional load on the overhead contact system when the tram is charging between stations; the sizing of onboard energy storage device for emergency feeding in a metro system.

Moreover the authors [1] considered the decoupled model of a traction vehicle including on-board hybrid accumulation system. The model is constructed especially to be used with power flow solvers for planning purposes.

Furthermore the authors [21] studied the on on-board energy storage model's influence on degradation of battery electric vehicles. The objective of created model is to maximize the harvest of the braking energy and minimize battery degradation in various driving styles.

In the article [8] the authors focused on use of renewable energy sources for traction power supply system. It was considered a new structure of railway power supply systems, energy storage systems and control algorithms under the conditions of stochastic mode of renewable energy sources operation. It was described directions for sustainable development of such systems and factors that influence the modes of operation of traction substations and electric networks.

In work [3] the authors analyzed the possibility of using of renewable energy sources for non-traction consumers. It was outlined the demands for selected types of rail traffic control devices.

To investigate the modes of stationary energy storage device there was a need to conduct tests in real conditions. 
For this purpose it was developed and built energy storage device in a short-circuit laboratory, which is located on a traction substation in Mińsk Mazowiecki [11-13]. The energy storage device was created in order to stabilize the voltage in the overhead contact line at a previously assumed level, to store recuperative energy, to reduce peak power consumed from the power system and to ensure the continuity of supplying the contact line for some time in case of failure. It is also possible to use energy from renewable energy sources that do not allow continuous energy supply to the traction line, but can charge the energy storage, which could supply the electric traction consumers.

\section{Construction, parameters and principles of energy storage}

The energy storage consists of a battery, protection system, DC / DC converter, filter and surge protection. The block diagram of the storage device is shown in fig. 1 .

The battery consists of lithium-iron batteries with a capacity of $200 \mathrm{Ah}$, operating voltage $2.8 \mathrm{~V}-4.0 \mathrm{~V}$, rated discharging current $200 \mathrm{~A}$, long-lasting discharging current $600 \mathrm{~A}$, impulse discharging current $2000 \mathrm{~A}$, rated charging current $100 \mathrm{~A}$, maximum charging current $600 \mathrm{~A}$, operating temperature $-45^{\circ} \mathrm{C}-+85^{\circ} \mathrm{C}$. The battery charging and discharging cycle is supervised by the BMS (Battery Management System) and determination of the maximum allowable charging and discharging current, voltage measurement - indication of the minimum and maximum voltage on cells, temperature measurement of each cell, protection against discharge and overcharge, balancing, control of protection. Data collected by the BMS are sent to the DC / DC converter $[11,13]$.

Figure 2a shows the installed DC / DC converter in the short-circuit laboratory of the Railway Institute. DC / DC converter (fig. 2a, 2b) supervises the battery charging and discharging current and adjusts the output voltage level of the energy storage device to the assumed value. The energy storage can be freely controlled on the DC / DC converter control panel (fig. 2b) The block diagram of the storage device is displayed on the touch panel, after pressing the given item, data on its status is displayed. The control allows setting thresholds for switching on modes of operation - loading and unloading the storage device. The converter has a continuous power of $350 \mathrm{~kW}$, a 15 -minute power of $1.1 \mathrm{MW}$, an operating voltage of $0-4.1 \mathrm{kV}$. The converter has its own short-circuit protection.

Short circuits and overload currents on the $3 \mathrm{kV}$ side are breaking by a BWSe-1000 type high speed breaker (fig. 3a). The release current has been set to $600 \mathrm{~A}$. 


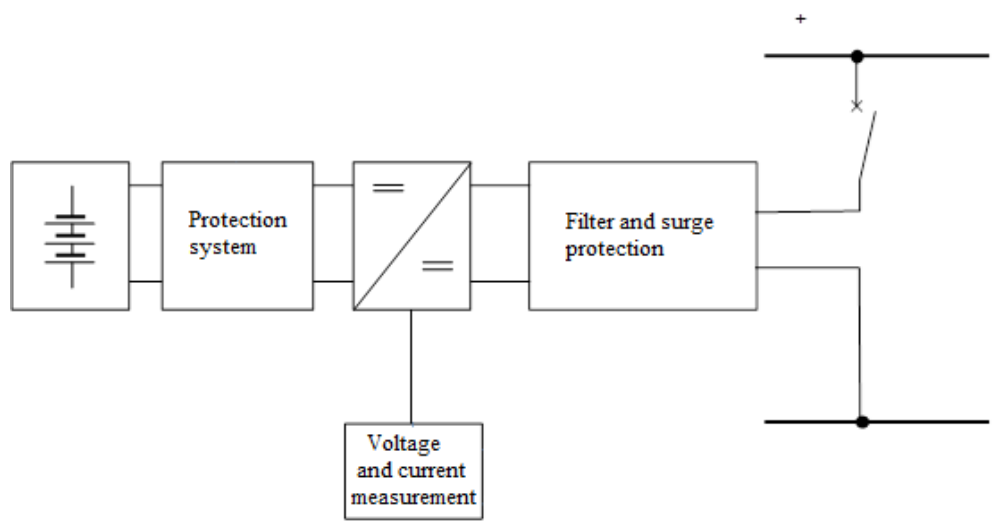

Fig. 1. Block diagram of an energy storage device $[11,13]$

a)

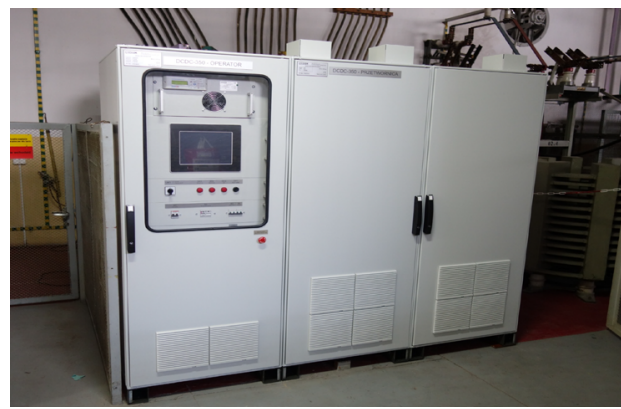

b)

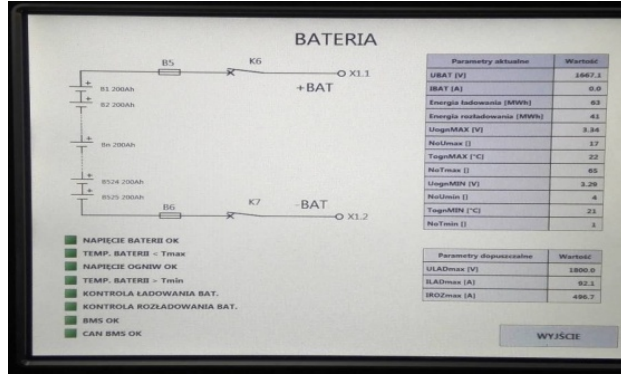

Fig. 2. a) DC / DC-350 converter in a short-circuit laboratory [9]; b) View of the inverter control panel - sample data sent by the BMS (Battery Management System) to the inverter [13]

a)

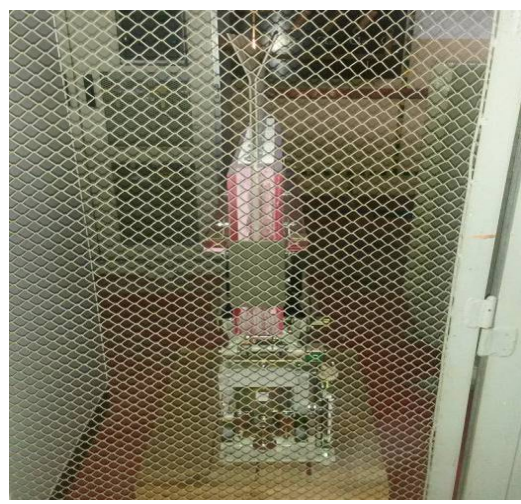

b)

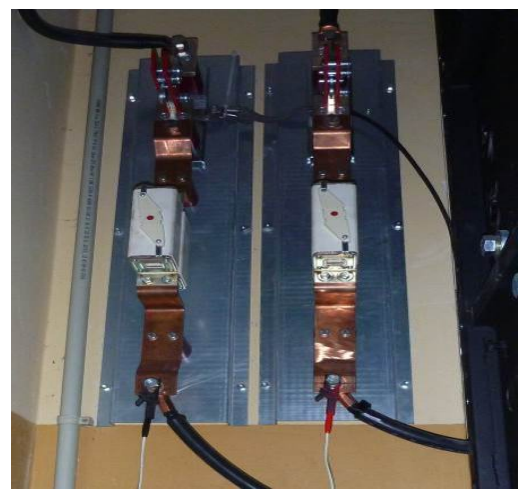

Fig. 3. Protection of energy storage device, a) High speed breaker BWS-1000[9]; b) Fuses and disconnectors at both poles of the battery [13] 
The location of the energy store is optional, it can be on the traction substation and on the area of section cabin. A block diagram of the inclusion of energy storage in the electric traction supply system is shown in fig. 4 .

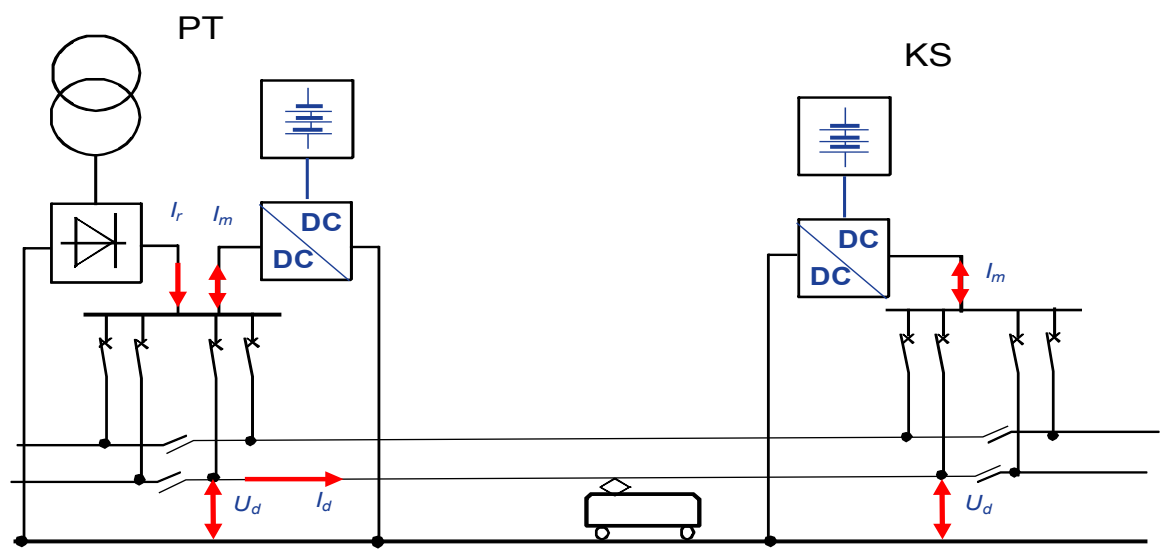

Fig. 4. Places for installation of the energy storage device in the electric traction power supply system, where: $P T$ - traction substation, $K S$ - section cabin, $I_{d}$ - total load current of the rectifier unit and energy storage, $I_{m}$ - energy storage device current, $U_{d}$ - voltage at clamps on $3 \mathrm{kV}$ energy storage side - inverter, $I_{r}$ - rectifier unit load current $[11,13]$

The storage device is switched between charging and discharging modes after setting of the voltage limits $U_{c l}, U c_{2}, U d_{1}, U_{d 2}$. The energy storage charging process begins when the voltage on the traction line side reaches $U_{c 2}$ voltage level and continues until it drops to $U_{c l}$ voltage level. The charging current is automatically selected by BMS in such a way that the network voltage does not fall below the $U_{c 2}$ value. The energy storage device discharge mode begins when the voltage at the input point drops below $U_{d l}$ and continues until the traction line voltage increases to the $U_{d 2}$ level or until the batteries are completely discharged (voltage drop at the cells defined as minimal).

\section{Energy storage device tests}

\subsection{Energy storage device during laboratory tests}

Figure 5 shows the measuring system proposed by the authors. Measuring system consisted of a rectifier unit, energy storage and high power resistors, acting as a load. The change of load parameters was carried out by means of contactors plugged into the circuit, breaking of which caused the shorting of some resistors. As a result, it was possible to obtain increased values of the energy storage load. 


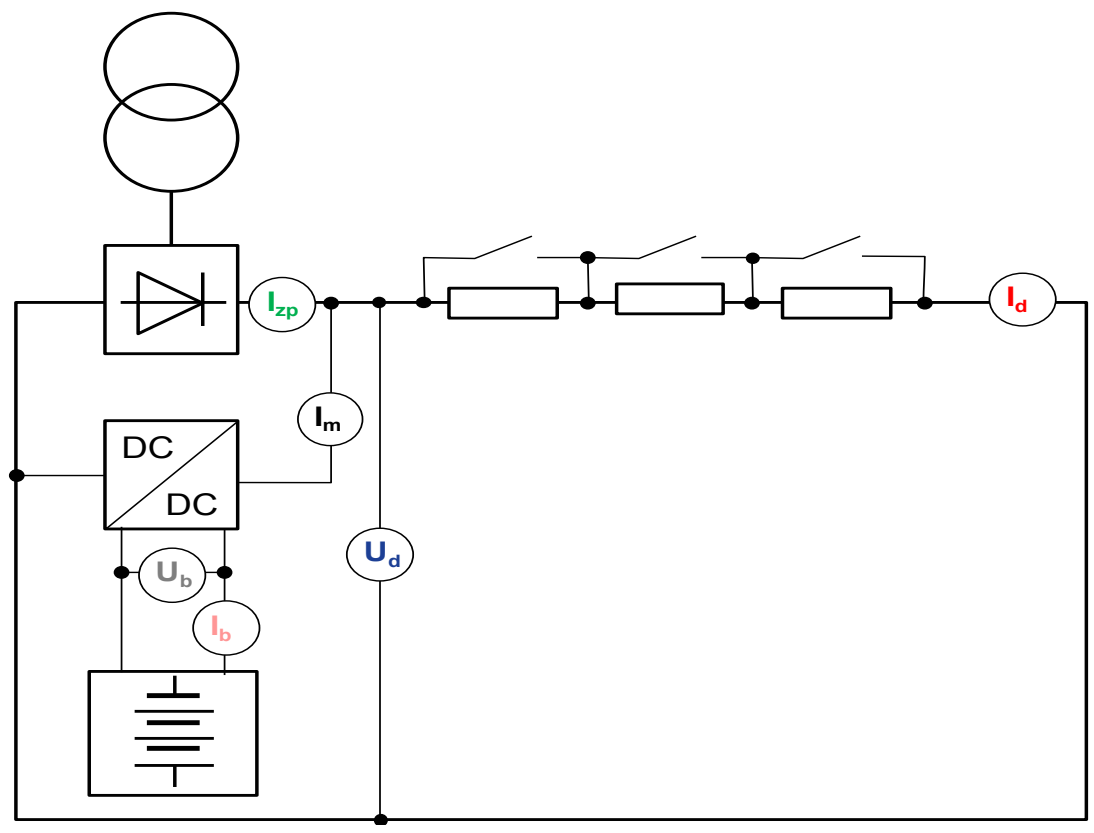

Fig. 5. Diagram of a measuring system for energy storage laboratory tests [13]

The rectifier was disconnected during the tests. $U_{d l}$ voltage was $2600 \mathrm{~V}$, the maximum battery discharge current was $I_{b}=250 \mathrm{~A}$. The change of current $I_{d}=I_{m}$ was implemented by switching on the appropriate contactors in the measuring system.

During the tests, the values of voltages and currents were recorded, marked in the waveforms and drawings as follows: [9] $I_{d}$ - total load current of the rectifier unit and energy storage device (red, channel 2-3); $I_{z p}$ - load current of the rectifier unit (green, channel 1-3 or 1-4); $I_{m}$ - energy storage current (black, channel 2-1), a positive value indicates energy delivery from the storage device, a negative value - storage device charging; $I_{b}$ - battery current (pink, channel 1-2), a positive value indicates battery energy discharging, a negative value - battery charging; $U_{d}$ - voltage at the clamps at $3 \mathrm{kV}$ side of the energy storage deviceconverter (blue colour, channel 2-2); $U_{b}$ - voltage at the battery clamps- converter connection from the battery side (gray colour, channel 1-1).

Figure 6 shows the current-voltage waveform from laboratory tests. 


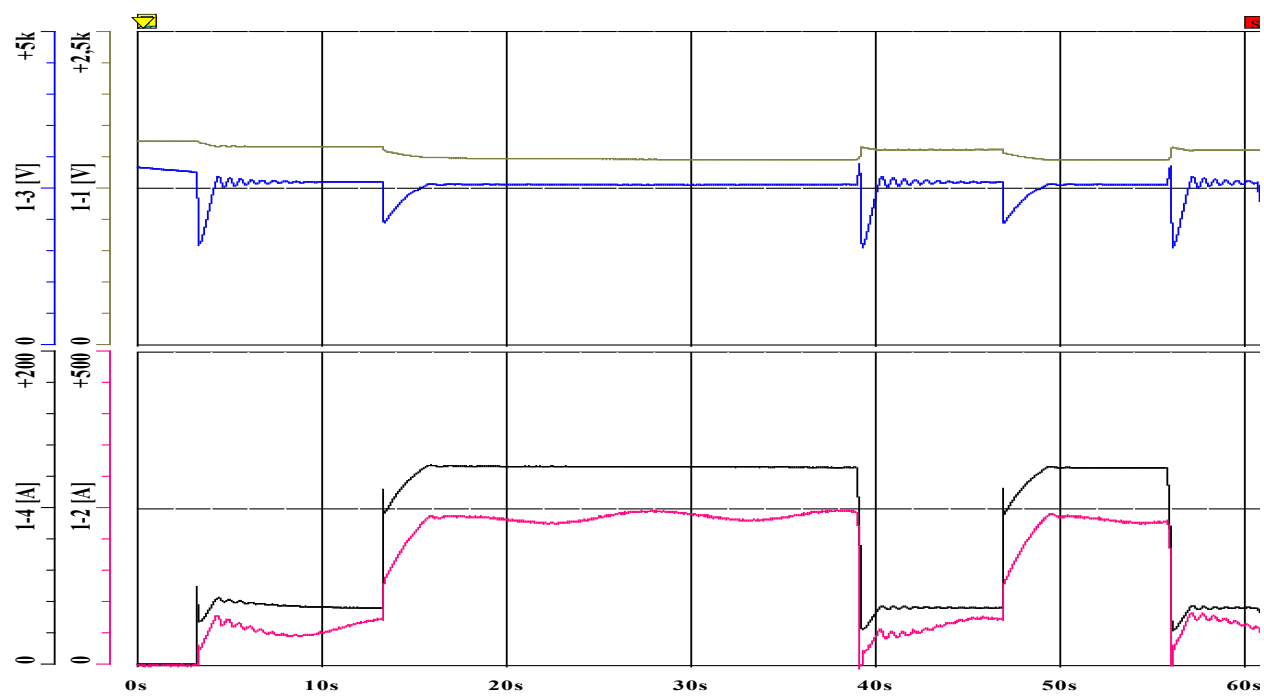

Legend:

\section{Ud-voltage at the clamps at $3 \mathrm{kV}$ side of the energy storage device-comerter Isp-load current of the rectifier unit \\ Im- energy storage current \\ Id-total load current of the rectifier whit and energy storage device}

Fig. 6. Voltage and current waveforms with load of storage device changing in the range 0 - 36 - 128 A [13]

The step change in current results from switching on or breaking the switches bypassing the load resistors, which causes temporary voltage fluctuations $U_{d}$. The current reaches the value determined in an oscillating manner which is caused by a significant value of capacitance and inductance at the output of the DC / DC converter at $3 \mathrm{kV}$ side.

\subsection{Energy storage device located in a traction substation}

The energy storage device was connected to the main bus of the IK short-circuit laboratory, the last one - to the bus $3 \mathrm{kV}$ DC switchgear in the Mińsk Mazowiecki traction substation. During tests, the traction line on the Warsaw-Siedlce railway line was supplied from a 6-pulse rectifier unit with a 4.4 MVA transformer from the IK short-circuit laboratory. Substation rectifiers were disconnected. The scheme of the measuring system is shown in fig. 7. 


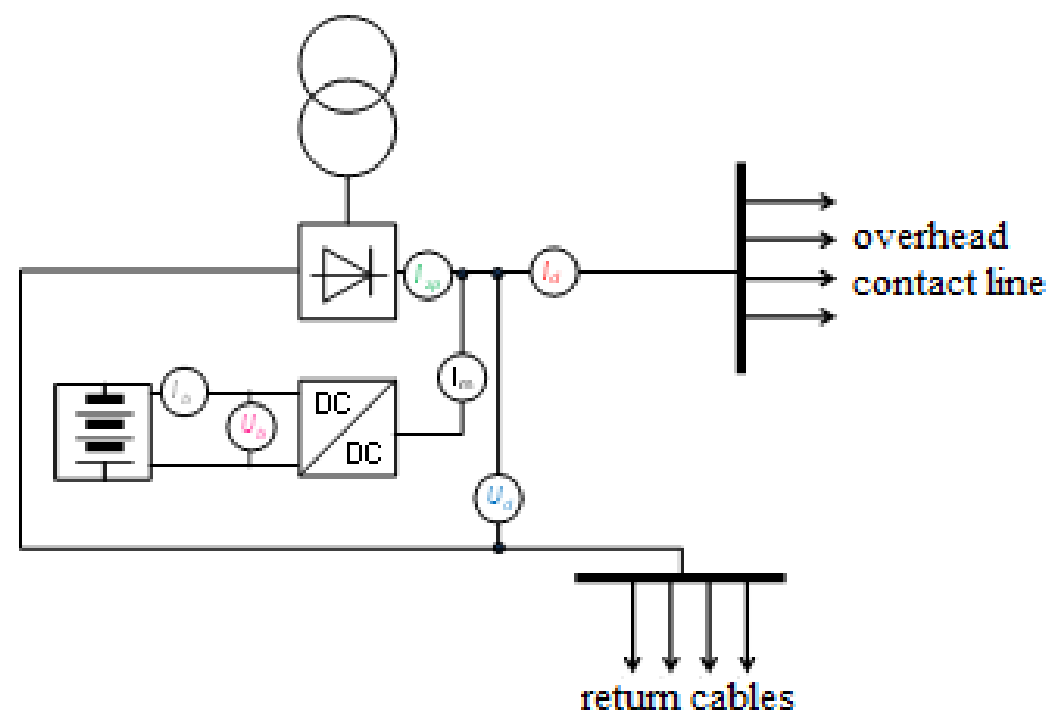

Fig. 7. Simplified diagram of the system for testing the energy storage in the traction substation system [13]

Examples of voltage and current waveforms in the system are shown in figs. 8-9. Figure 8 shows the waveforms when the energy storage is in charging mode. When the storage device is in charging mode, the load current of the rectifier unit is $I_{z \mathrm{p}} \approx 0$, which shows that the storage device was charged from the traction line, probably by energy from regenerative braking, which is evidenced by the high voltage value $U_{d}$. In fig. 9, the energy storage device is being discharged, can observe an attempt to stabilize $U_{d}$ voltage at the $U_{d l}$ level. This confirms the increase of the storage device current $I_{m}$ with the simultaneous increase of the current Id and the voltage drop $U_{d}$. Due to the limited current efficiency of the storage device $\left(I_{\max } \approx 300 \mathrm{~A}\right.$ ), which is additionally dependent on the degree of storage battery charge, it is not possible to stabilize the voltage $U_{d}$ at a level $U_{d l}$ many times. 


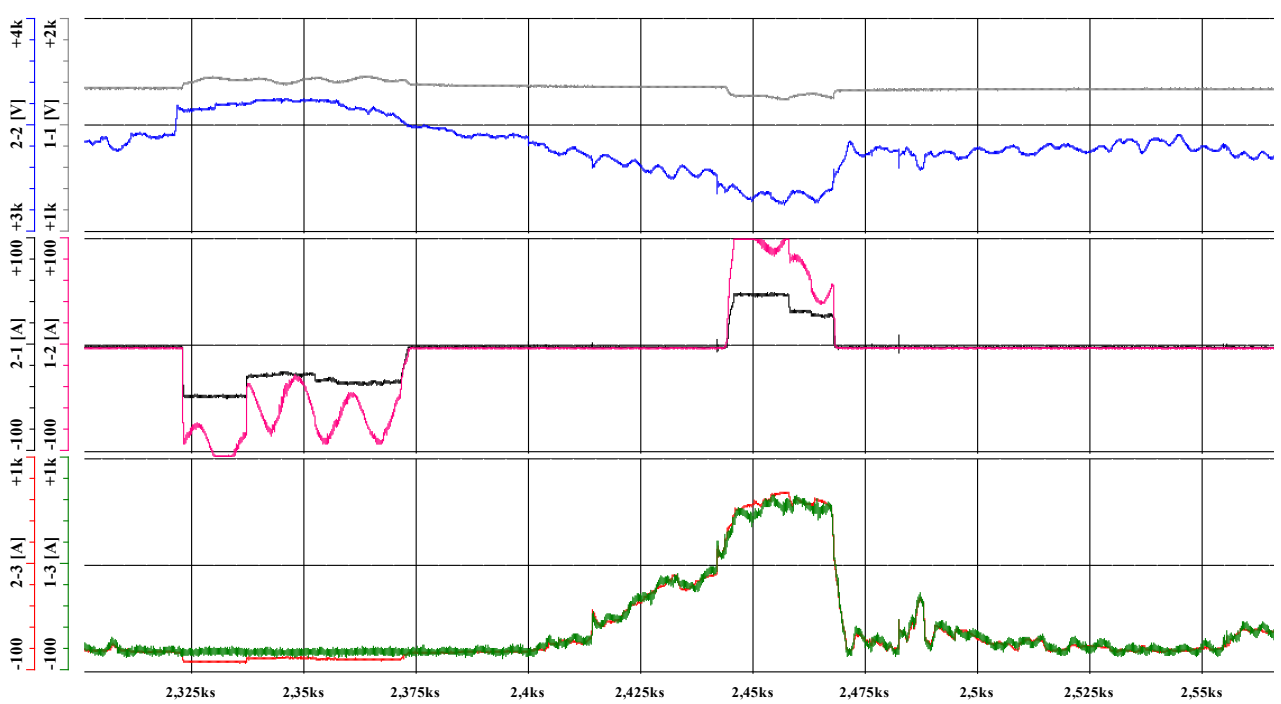

Legend:

Ud-voltage at the clamps at $3 \mathrm{kV}$ side of the energy storage device-comverter

Isp-load curent of the rectifier wnit

Im-energy storage current

Id-totsl load current of the rectifier unit and energy storage device

Ib- batteny curvent

Ub-voltage at the battery clamps-comerter connection from the battery side

Fig. 8. Voltage and current waveforms in the energy storage and traction substation system with $U_{d l}=3200 \mathrm{~V}, U_{d 2}=3300 \mathrm{~V}, U_{c l}=3450 \mathrm{~V}$ and $U_{c 2}=3500 \mathrm{~V}[13]$ 


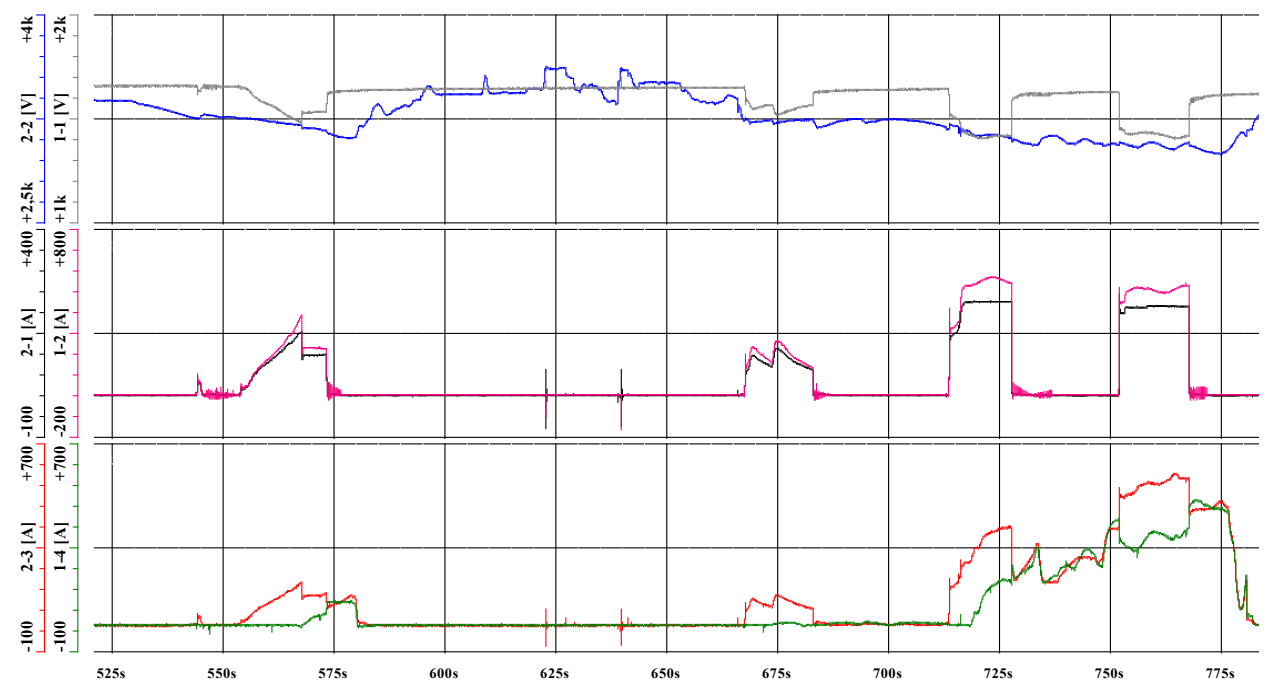

Legend:

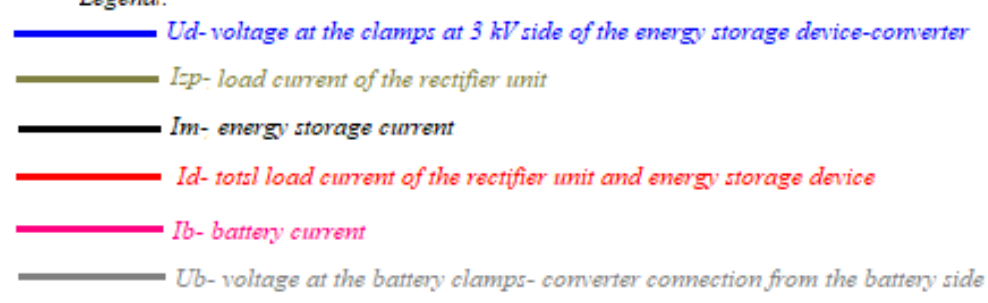

Fig. 9. Voltage and current waveforms in the energy storage and traction substation system at $U_{d l}=3300 \mathrm{~V}, U_{d 2}=3400 \mathrm{~V}, U_{c l}=3500 \mathrm{~V}$ and $U_{c 2}=3600 \mathrm{~V}[13]$

\subsection{Energy storage located in the section cabin}

The section cabin was simulated in the Mińsk Mazowiecki traction substation by disconnecting all rectifier units, locking of high speed breakers at all power supply feeders. Figure 10 shows the energy storage in charging mode. It is not possible to determine by switching off rectifier units whether the storage device was charged by energy generated during regeneration or from an adjacent traction substation. Figure 11 shows energy storage device in discharge mode. This occurred because of the drop of voltage $U_{d}$ drop below $U_{d l}$. There are also noticeable breaks in the operation of the storage device as a result of significant values of current $I_{b}$ up to $500 \mathrm{~A}$. 


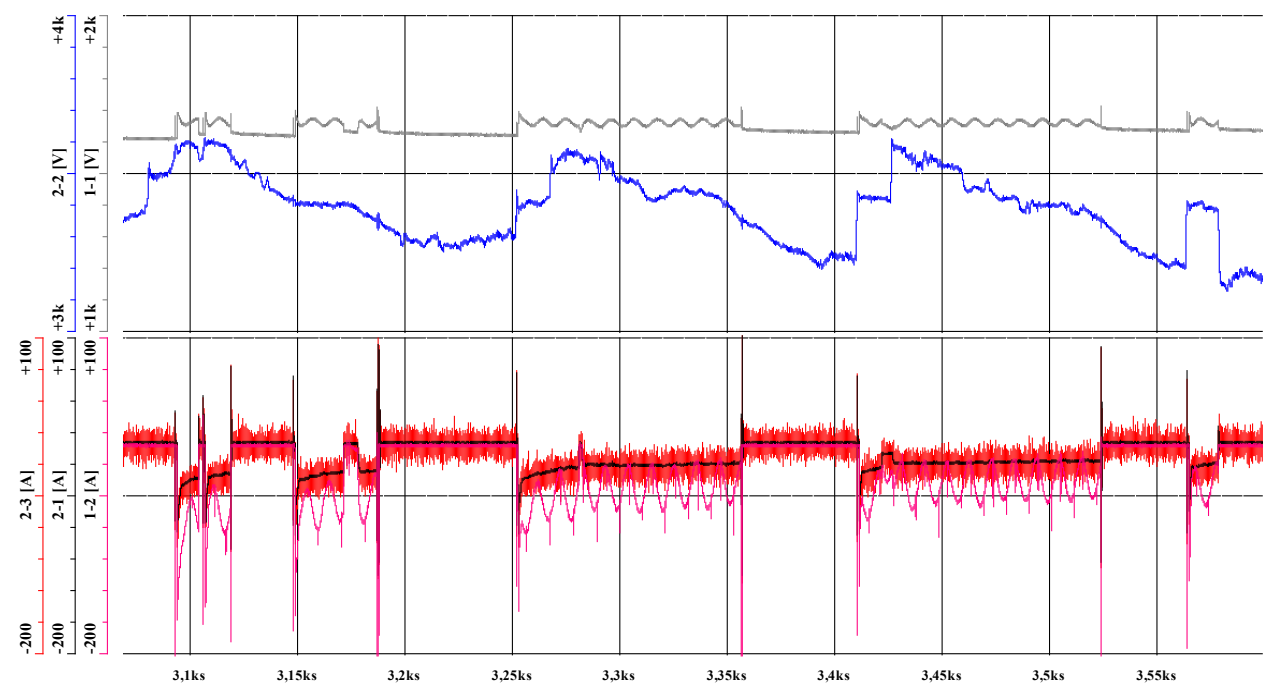

Legend:

Ud-voltage at the clamps at $3 \mathrm{kV}$ side of the energy storage device-converter

Im- energy storage current

Id- totsl load current of the rectifier wnit and energy storage device

Ib- batteny curvent

Ub- voltage at the battery clamps- converter connection from the battery side

Fig. 10. Voltage and current waveforms in the energy storage system during charging when the traction substation is operating in the cabin mode at $U_{d l}=3200 \mathrm{~V}, U_{d 2}=3300 \mathrm{~V}$, $U_{c 1}=3400 \mathrm{~V}$ and $U_{c 2}=3500 \mathrm{~V}[13]$ 


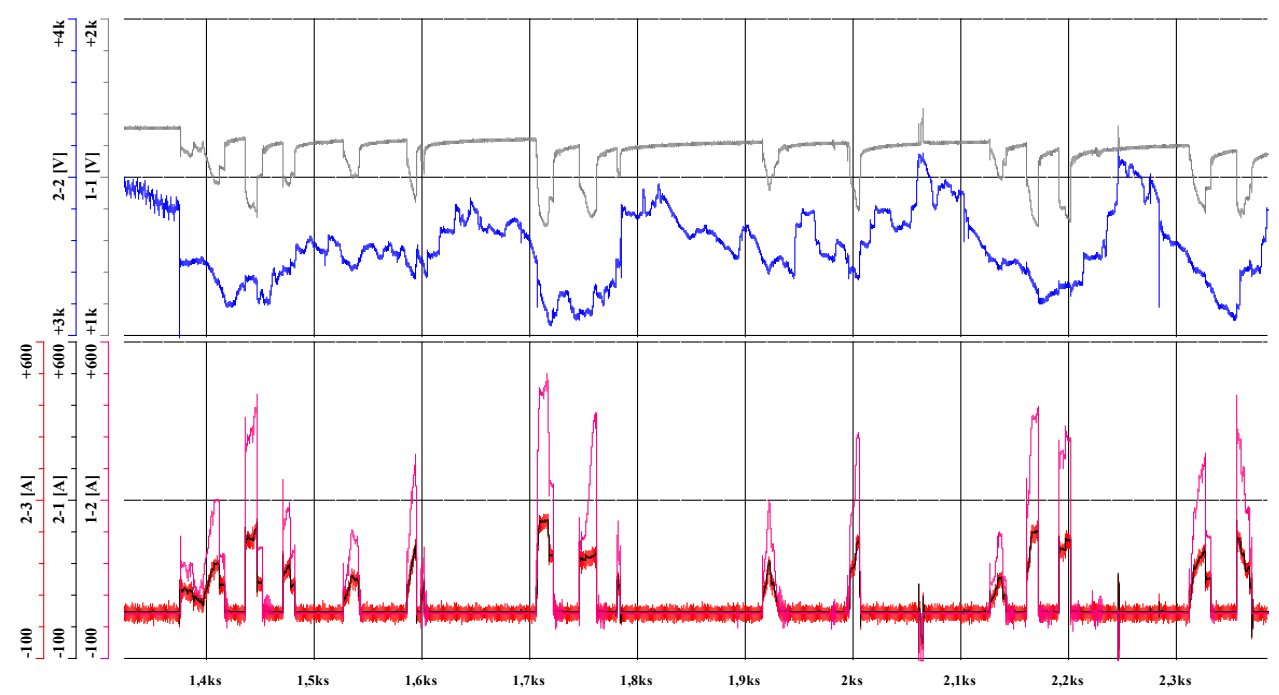

Legend:

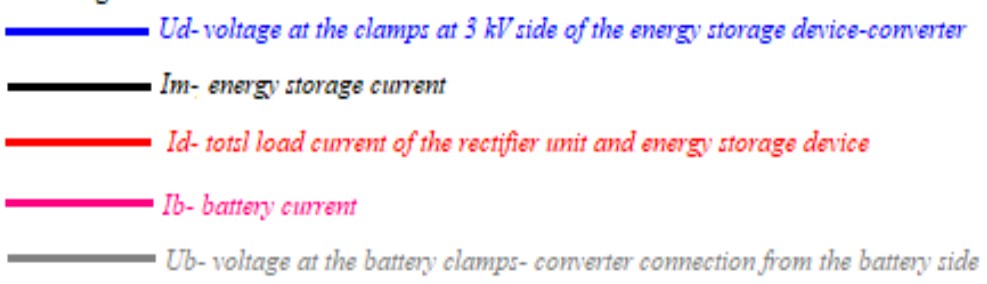

Fig. 11. Voltage and current waveforms in the energy storage system during its discharge when the traction substation is in the cabin mode at $U_{d l}=3200 \mathrm{~V}, U_{d 2}=3300 \mathrm{~V}, U_{c l}=3400 \mathrm{~V}$ and $U_{c 2}=3500 \mathrm{~V}[13]$

\section{Conclusion}

Laboratory and real-life tests show that the energy storage device is able to support the operation of the railway traction power supply system.

The storage device goes into charging mode when the traction substation is operating in idle state or at low load. The discharge mode may depend on the output voltage of the traction substation or the load current of the rectifier unit. In the first situation, the storage device stabilizes the voltage value at the assumed level even for heavy loads. In the second situation, the current that is taken from the energy storage device compensates the increase of load current of traction substation above the assumed maximum of rectifier current value. This is possible when the substation load current is less than the sum of the maximum storage device current and the assumed load current of the rectifier units. 
Full controllability of the storage device demonstrates its universality - thanks to the variability of parameters such as energy capacity, operating voltage, values of charging and discharging currents, voltage levels switching charging and discharging modes - it is possible to use it in all DC and municipal traction power supply systems.

The above arguments prove the need to continue research related to energy storage device in the electric traction supply system.

\section{Acknowledgment}

This paper is elaborated in the framework of the project co-financed by the Polish National Agency for Academic Exchange (project PPN/BUA/2019/1/00016/U/00001)

\section{References}

1. Arboleya P., El-Sayed I., Mohamed B., Mayet C.: Modeling, Simulationand Analysis of On-Board Hybrid Energy Storage Systems for Railway Applications. Energies, No. 12(11) 2019, DOI 10.3390/en12112199.

2. Bartłomiejczyk, M., Jarzebowicz, L.: Energy savings by application of supercapacitor storage in trolleybus supplying station - analysis of experimental results" XVI National Scientific Conference of Electric Traction SEMTRAK 2014.

3. Bialon A., Kuznetsov V., Hubskyi P., Ostapchuk O.: Proposals for the Use of Renewable Energy Sources for Traffic Control Devices Power Supply. Transport Means 2020 - Proceedings of the 24th International Scientific Conference. Part I, 2020.

4. Biliński J., Figat J., Milewski D.: Tram with battery accumulator - concept and tests" XVI National Scientific Conference of Electric Traction SEMTRAK 2014.

5. Dąbrowski J.: Supercapacitor storage for $3 \mathrm{kV} \mathrm{DC}$ traction system. 11th International Conference Modern Electric Traction MET'2013.

6. Maciołek, T.: The use of energy storage in the railway traction $3 \mathrm{kV} \mathrm{DC}-$ not too distant prospect? Railway Transportation Technology, no. 9/2015.

7. Maciołek T., Drążek Z., Szeląg A.: Energy efficiency energy storage in substations of $3 \mathrm{kV}$ DC system. Logistics, no. 3/2015.

8. Ostapchuk O., Kuznietsov M., Kuznetsov V., Kuznetsov V.: Problems of the use of renewable energy sources in the structure of railway power supply. IOP Conference Series: Materials Science and Engineering, 2020.

9. Pawełczyk M.: On possibilities of utilization of energy storage in electric traction systems" 12th International Conference Modern Electrified Transport MET'2015.

10. Radu PV., Lewandowski M., Szelag A.: On-Board and Wayside Energy Storage Devices Applications in Urban Transport Systems - Case Study Analysis for Power Applications. Energies, 2020, No. 13(8), DOI 10.3390/en13082013.

11. Rojek A.: Electric energy storage in DC traction power supply systems. Proceedings of 7th Transport Research Arena TRA, Austria 2018. 
12. Rojek A.: Method of assistance of electric power DC catenary and support system for the supply of electric DC catenary" Patent application P.418188.

13. Rojek A., Skrzyniarz M.: Energy storage as a device supporting the operation of a traction substation. Works of the Railway Institute, No. 165, Warsaw 2020.

14. Solatek T.: Assessment of the possibility of braking energy recovery in tramway traction. 7th International Conference "Modern Electric Traction in Integrated XXIst Century Europe" MET'2005.

15. Solatek T.: Purposefulness and cost-effectiveness of using regenerative braking energy capacitors on tram substations. XIV National Scientific Conference of Electric Traction SEMTRAK 2010.

16. Setlak R, Fice M.: Smart hybrid drive with supercapacitor storage. XVI National Scientific Conference of Electric Traction SEMTRAK 2014.

17. Staroński K.: Control system for stationary supercapacitors energy storage. XVI National Scientific Conference of Electric Traction SEMTRAK 2014.

18. Wieczorek M., Lewandowski M." Hybryd Energy storage system for electric vehicle. XVI Ogólnopolska Konferencja Naukowa Trakcji Elektrycznej SEMTRAK 2014.

19. https://www.nakolei.pl/zielona-kolej-pkp-energetyka-ma-plan/ [access:

04.01.2020].

20. www.ec.europa.eu/clima/policies/strategies/2030_en [access: 04.01.2020].

21. Zhang C., Wang D., Wang B., Tong F.: Battery degradation minimization-oriented hybrid energy storage system for electric vehicles. Energies, 2020, No. 13(1), DOI 10.3390/en13010246. 